\title{
Alpine foreland running drier? Sensitivity of a drought vulnerable catchment to changes in climate, land use, and water management
}

\author{
Clara Hohmann ${ }^{1,2}$ (D) Gottfried Kirchengast ${ }^{1,2,3}$. \\ Steffen Birk ${ }^{2,4}$
}

Received: 29 March 2017 / Accepted: 1 December 2017 / Published online: 23 December 2017

(C) The Author(s) 2017. This article is an open access publication

\begin{abstract}
Southeastern Austria as part of the southeastern Alpine forelands experiences an increase of temperature and a tendency of decreasing precipitation. Especially in summer, the temperature strongly increased by about $0.7^{\circ} \mathrm{C}$ per decade since the 1970 s. Drought vulnerability under climate change is therefore a key question in this region. Here, we address this question by exploring the hydrological sensitivity of the Raab catchment in Austria (area $987 \mathrm{~km}^{2}$ ), a typical catchment in these Alpine forelands. Using the process-oriented Water Flow and Balance Simulation Model (WaSiM) over 1982-2011, we focus on low-flow conditions during extended summer (May-September) and analyze the catchment's runoff sensitivity to climate change, but also land use and water management change. We find that climate change drivers dominate the summertime runoff response (decrease $>40 />70 \%$ ), based on moderate and strong climate change cases in the region (temperature $+2 /+4 \mathrm{~K}$, precipitation $-15 /-30 \%$ ). Land use changes towards more dry and sealed areas enhance surface runoff and thus may lead to somewhat increased flood peaks. In contrast, water withdrawal for irrigation reduces runoff during low-flow periods in the summer when the irrigation demand is high. Although the impact of these non-climatic drivers on runoff generally is lower than that of the climate change considered, their interactive effects may reinforce the catchment's tendency of running drier during summer. While more detailed
\end{abstract}

Electronic supplementary material The online version of this article (https://doi.org/10.1007/s10584-0172121-y) contains supplementary material, which is available to authorized users.

Clara Hohmann

clara.hohmann@uni-graz.at

1 Wegener Center for Climate and Global Change (WEGC), University of Graz, Graz, Austria

2 FWF-DK Climate Change, University of Graz, Graz, Austria

3 Institute for Geophysics, Astrophysics, and Meteorology/Institute of Physics, University of Graz, Graz, Austria

4 Institute of Earth Sciences, NAWI Graz Geocenter, University of Graz, Graz, Austria 
scenario-based assessments are needed to further assess drought risks, this initial study provides clear evidence for the vulnerability of Alpine foreland catchments to increasing summer dryness under climate change.

Keywords Catchment hydrology $\cdot$ Climate change $\cdot$ Sensitivity analysis $\cdot$ Environmental changes $\cdot$ Drought vulnerability

\section{Introduction}

The impact of climate and environmental changes on hydrology is an important aspect of water management and stakeholder decisions. The widely used scenario approach uses different climate projections for the assessment of impacts on water resources (Blöschl and Montanari 2010; Vano and Lettenmaier 2014; Wagner et al. 2017). But especially for precipitation, the input of primary importance for hydrological models, future scenarios are often very uncertain (Mishra et al. 2017; Wagner et al. 2017). A scenario-neutral approach is increasingly used for climate impact studies, since it is independent of climate change projections (Prudhomme et al. 2010; Brown and Wilby 2012). The overall idea is to acquire a better understanding of the uncertainties and to understand the predicted or projected changes (Blöschl and Montanari 2010). A sensitivity-based approach can help to better understand the system, does not need computationally intensive simulations, and is not necessary to update when new climate models are available (Vano and Lettenmaier 2014). As a foundation on physically consistent climate scenarios is lacking, the approach has its own limitations, though, and should be viewed as complementary to the scenario-based approaches.

Hydrological changes may not only result from climatic changes; also, other environmental changes like land use and water management strongly influence the water balance. When focusing on hydrological changes in the future, the distinction between the important drivers like changes of climate, land use, and water management is quite difficult. Especially on a catchment scale, climate changes might trigger land use and water management changes, and also adaptation strategies should be considered. Often, it is hard to distinguish between the effects of different changes. Therefore, we will analyze the different changes separately and in various combinations to achieve a better understanding of the hydrologic effects of different environmental changes.

For this study, the Raab catchment in southeastern Styria/Austria suits very well, since it is located within the southeastern Alpine forelands, a transition zone between the Alpine and the Mediterranean region which is especially vulnerable to climate change (Section 2). One of the effects of the warming summers might be a stronger vulnerability to drought. Laaha et al. (2016) recognized for this region a decreasing trend of low-flow runoffs, which means the catchments become drier. The Styrian Raab catchment was already affected by drought years in the recent past (e.g., 1992, 2001, 2003). With the temperature increase and a potential decline of precipitation amount in the future, droughts may occur more frequently especially in summer. In the present time, the human activities also have a significant influence on droughts and should be coconsidered (Van Loon et al. 2016). For our analysis, we focus on low flow in the summer months to get a better understanding of the drought vulnerability of the Raab catchment. 
Streamflow data of the recent past are used to calibrate and validate a process-oriented hydrological model (Section 3.1). The model provides the opportunity to investigate the possible effects of different long-term changes, which are normally slow processes with evolving interactions, by a sensitivity analysis. This study focuses on the hydrological sensitivity of the Raab catchment to climate, land use, and water management changes (Section 3.2), thus providing valuable information about possible low-flow hydrological futures within this and similar vulnerable catchments (Section 4). In particular, the results help to answer two questions (Section 5): (1) How does summer runoff and evapotranspiration respond to the different changes (drivers) and what are the characteristics of these driverresponse relationships? (2) How do the anthropogenic non-climatic effects, i.e., changes in land use and irrigation, interact with climate change in a drought-vulnerable catchment? We close the paper with giving the main conclusions (Section 6).

\section{Study region}

The Raab is a typical southeastern Alpine foreland river, originating in the uplands of the eastern-most Alpine ridges in Austria (see the map in Fig. 1). The Raab's source is located in the "Passailer" Alps in the state of Styria, at a height of around $1150 \mathrm{~m}$ a.s.l. The Raab flows towards the southeast through Austria (states of Styria and Burgenland) and continues through Hungary where it ends as a tributary of the Danube. We focus on the Styrian Raab catchment (Fig. 1) up to gauging station Neumarkt (including a small part of Burgenland), with a river length of about $95 \mathrm{~km}$ and a catchment size of $987 \mathrm{~km}^{2}$. The land use is dominated by agriculture (42\%) and forest (40\%), and the main soil texture is loam (50\% silty loam and $41 \%$ loam) (Supplementary Fig. S1).

The region is especially interesting to study, since regional climate change is already clearly measurable, potentially because the global warming trend is regionally amplified by a simultaneous increase in solar irradiation related to a reduction of aerosols over the last few decades (Auer et al. 2007; Folini and Wild 2011; Nabat et al. 2014). The temperature in this Alpine foreland region, including the Raab catchment from about the City of Weiz southward, shows a strong summer temperature trend with an increase of near $0.7{ }^{\circ} \mathrm{C}$ per decade from 1971 to 2016 (Fig. 1, lower left panel; cf. also Kabas et al. 2011). Compared to the recent global warming trend of near $0.2{ }^{\circ} \mathrm{C}$ per decade since the 1970s (Willett et al. 2016; GISTEMP Team 2017), this change is more than three times as strong; compared to near $0.5{ }^{\circ} \mathrm{C}$ per decade over the European Alpine region (Gobiet et al. 2014), it is still almost 50\% stronger. The precipitation trend is not distinct; the summer precipitation only shows a slight decrease near $1 \%$ per decade from 1971 to 2016 (Fig. 1, lower right panel). Yet, climate projections suggest that decreases in the order of 10-20\% within the twenty-first century are realistic (Gobiet et al. 2014). Likewise, the river Raab exhibits only slightly decreasing summer streamflow (approximately 3\% per decade; see Supplementary Fig. S2). Nevertheless, potential future decreases in precipitation bear the risk of amplifying the reduction of summertime streamflow resulting from enhanced evapotranspiration in a warming climate. This is the drought vulnerability narrative that we explore in this study.

The catchment can be split up into three parts (color tones in the map of Fig. 1): the upper Raab down to gauging station St. Ruprecht, with more forest and mountainous areas; the middle Raab from St. Ruprecht down to station Takern II, with less hilly areas 

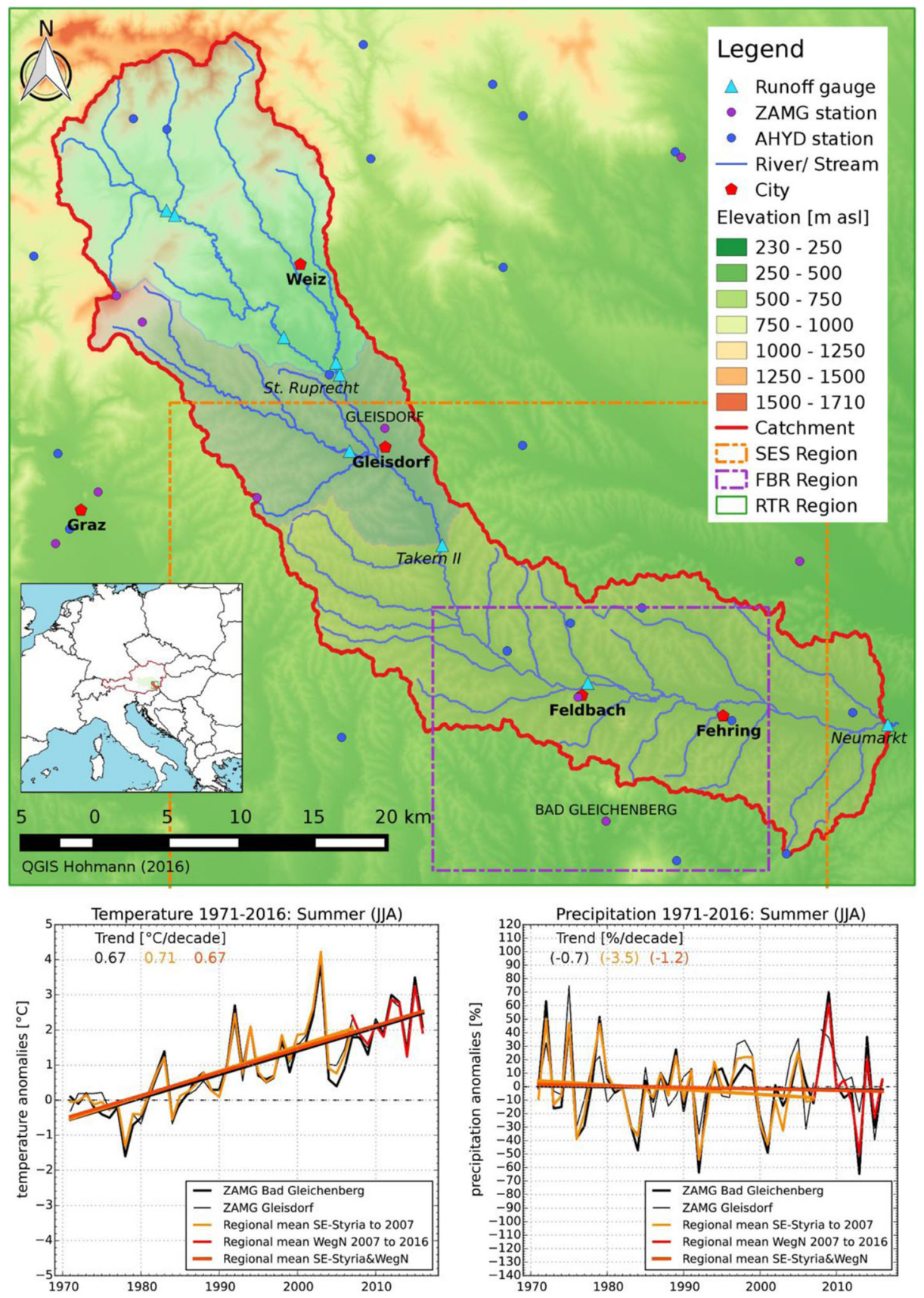

Fig. 1 Upper panel: map of the Raabtal region (RTR) located in southeastern Austria (see lower left inset), including the Styrian Raab catchment (red; with upper, middle, and lower sub-basins in different colors). Digital elevation model topography and other information elements such as station locations are shown as background and complementary information (see legend; southeastern Styria (SES) and Feldbach region (FBR, WegenerNet) are intensively studied sub-regions; Kabas et al. 2011; Kirchengast et al. 2014). Lower panels: summer (JJA) temperature (left) and precipitation (right) anomaly time series (relative to the 1971-1990 average) and corresponding trends over 1971 to 2016, for different sub-regions and climate-quality stations in the catchment region 
dominated by agriculture and forest patches; and the lower Raab from Takern II down to station Neumarkt, with agriculture-dominated areas and patchy forests. We adopt the lower Raab as the focus region of this study, exhibiting the strongest anthropogenic imprints of the whole catchment. It includes the gauging station Feldbach, located between Takern II and Neumarkt, as interim station for runoff diagnostics.

\section{Data and methods}

\subsection{Hydrological model and input data}

We use the Water Flow and Balance Simulation Model (WaSiM), which was developed for climate change analysis in Alpine catchments by Schulla (1997). WaSiM is a well-established, distributed, deterministic, mainly physics-based and process-oriented hydrological model. The model was extensively used already and is thus well tested for climate change studies (e.g., Bürger et al. 2011; Gädeke et al. 2014) as well as for land use change studies (Alaoui et al. 2014; Yira et al. 2016). For our sensitivity analysis, we choose a reasonably simple model setup with WaSiM (Richards), version 9.09.08, with a daily time step (meteorological input, temperature, and precipitation) and a spatial resolution of $1 \mathrm{~km} \times 1 \mathrm{~km}$ for the grids (digital elevation model, land use, soil). The input data, resolution, and sources are summarized and illustrated in Supplementary Table S1 and Fig. S1.

The unsaturated zone is modeled by the Richards approach with a Van Genuchten parametrization after Carsel and Parrish (1988). The potential evapotranspiration is calculated using a parsimonious temperature approach after Hamon (1960), in order to keep the meteorological data requirements as simple as possible. The Hamon approach was also used in other climate change studies (Bürger et al. 2011; Wanders and Wada 2015) and showed a good performance in studies comparing different evapotranspiration models (Oudin et al. 2005; Bormann 2011). For an overview of all WaSiM modules used in this study, see Fig. 2, where also the processes affected by land use and water management changes are indicated. A detailed WaSiM description can be found in Schulla (2015).

The model was calibrated to runoff time series from 2003 to 2009 at three Raab stations (St. Ruprecht, Takern II, Neumarkt) using the shuffled complex evolution optimization algorithm developed at the University of Arizona (SCE-UA) (Duan et al. 1994). The time series from 1995 to 2001 was used for validation. Beside the total discharge, also the runoff components (direct flow, interflow, baseflow) were visually analyzed for validation purposes.

The model performance was assessed using the Nash-Sutcliffe efficiency (NSE) (Nash and Sutcliffe 1970) in its standard form and, to account for the low flow focus, its logarithmic version (log NSE; see Section S2 in the supplementary material). The mean NSE over the three stations is 0.74 for the calibration period and 0.64 for the validation, and the $\log$ NSE is 0.76 for the calibration and 0.74 for the validation period. After Moriasi et al. (2007), the model has a good NSE model performance. This indicates that this model setup is well suitable for the targeted sensitivity simulations of the Raab catchment. We note that a more process-based model setup (e.g., for evapotranspiration and groundwater) as well as further improved input fields (e.g., for land use and soil) could be used for a more detailed follow-on study, but this is beyond the scope of this initial study. See the supplementary material (Sect. S2) for further information about the model setup and calibration. 


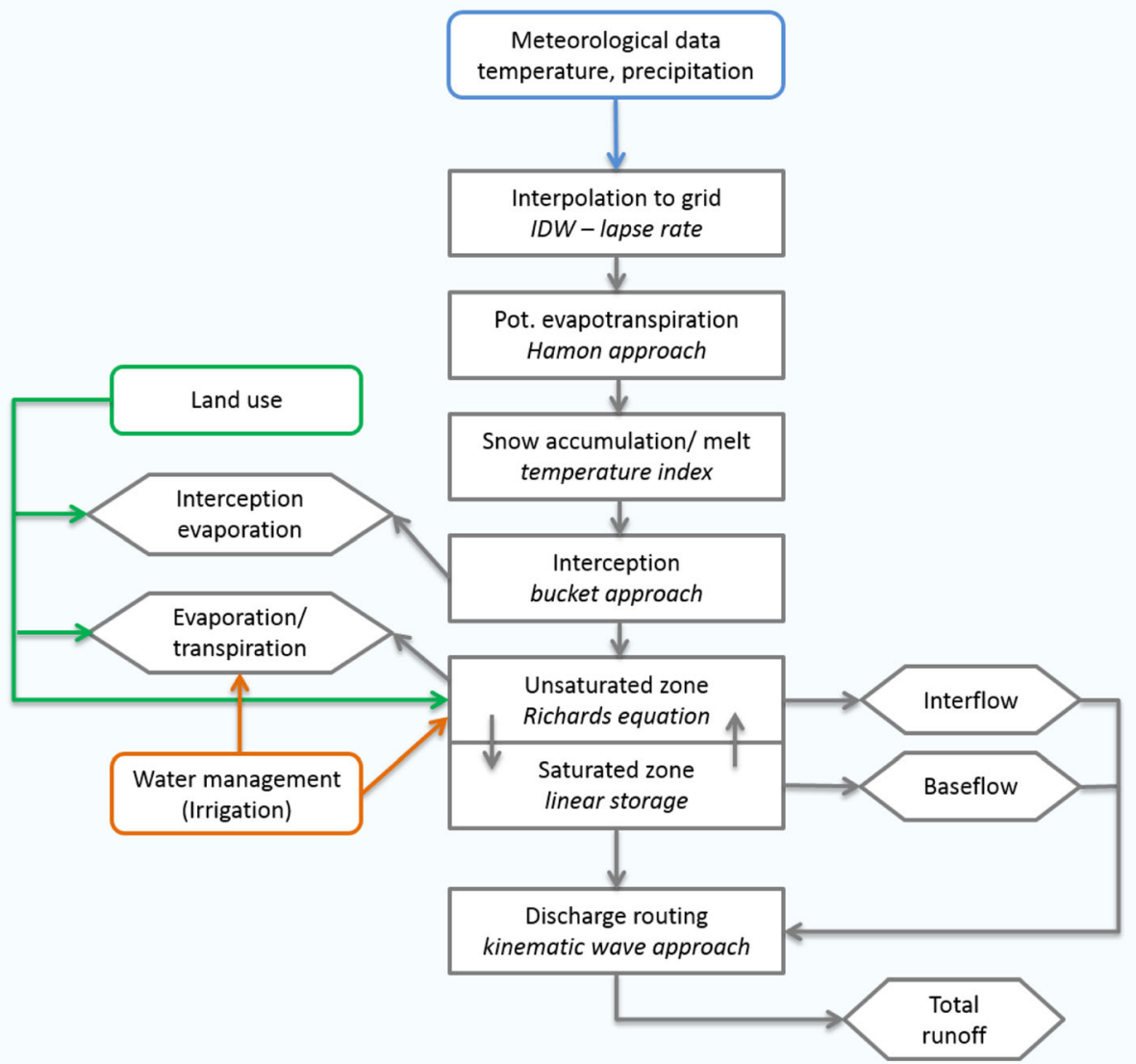

Fig. 2 WaSiM model structure used for the study; after Schulla (2015) and adding information on the chosen modeling approaches for specific main processes as well as indicating the driving influences focused on by the sensitivity analysis, climate change (blue, top), land use change (green, left), and water management change (orange, bottom left)

\subsection{Drought sensitivity analysis}

In order to analyze the sensitivity of the Raab catchment's hydrological response to possible future changes, different environmental changes are simulated. In the following, these different changes are described in detail (Table 1) and their implementation in WaSiM is specified (Fig. 2).

The temperature and precipitation changes (TC and PC, respectively) are based on the station time series of the recent past from 1982 to 2011 and applied to all days of the summer period. That is, every daily value of the extended summer season (May to September) is changed with an increase in temperature and/or a decrease in precipitation. We included moderate changes (temperature $+2 \mathrm{~K}$, precipitation $-15 \%$ ) and strong changes (temperature $+4 \mathrm{~K}$, precipitation $-30 \%$ ), which roughly reflect regional climate projections near the end of the century (e.g., Gobiet et al. 2014). A transition to less frequent but more intense rainfall, which has been suggested by climate models (e.g., Ban et al. 2015), is not considered here. Yet, the changes are only applied over the extended summer because climate change in the 
Table 1 Environmental change cases simulated and investigated in the low-flow sensitivity analysis

\begin{tabular}{|c|c|c|c|c|c|c|c|c|}
\hline \multirow{2}{*}{$\begin{array}{l}\text { Type of } \\
\text { change }\end{array}$} & \multicolumn{2}{|c|}{ Temperature } & \multicolumn{2}{|c|}{ Precipitation } & \multicolumn{2}{|l|}{ Land use } & \multicolumn{2}{|c|}{ Water management } \\
\hline & $\begin{array}{l}\text { Moderate } \\
(\mathrm{K})\end{array}$ & $\begin{array}{l}\text { Strong } \\
(\mathrm{K})\end{array}$ & $\begin{array}{l}\text { Moderate } \\
(\%)\end{array}$ & $\begin{array}{l}\text { Strong } \\
(\%)\end{array}$ & Moderate & Strong & Moderate & Strong \\
\hline $\mathrm{TC}$ & +2 & +4 & & & & & & \\
\hline $\mathrm{PC}$ & & & -15 & -30 & & & & \\
\hline LUC & & & & & $\rightarrow$ sealed & $\begin{array}{c}\rightarrow \text { sealed and } \rightarrow \\
\text { extensive } \\
\text { agriculture }\end{array}$ & & \\
\hline WMC & & & & & & & $\begin{array}{l}\text { Irrigation } \\
\text { threshold } \\
0.5\end{array}$ & $\begin{array}{l}\text { Irrigation } \\
\text { threshold } \\
0.8\end{array}$ \\
\hline $\mathrm{TP}$ & +2 & +4 & -15 & -30 & & & & \\
\hline TPL & +2 & +4 & -15 & -30 & $\rightarrow$ sealed & $\begin{array}{c}\rightarrow \text { sealed and } \rightarrow \\
\text { extensive } \\
\text { agriculture }\end{array}$ & & \\
\hline TPLW & +2 & +4 & -15 & -30 & $\rightarrow$ sealed & $\begin{array}{c}\rightarrow \text { sealed and } \rightarrow \\
\text { extensive } \\
\text { agriculture }\end{array}$ & $\begin{array}{l}\text { Irrigation } \\
\text { threshold } \\
0.5\end{array}$ & $\begin{array}{l}\text { Irrigation } \\
\text { threshold } \\
0.8\end{array}$ \\
\hline
\end{tabular}

$T C$ temperature change, $P C$ precipitation change, $L U C$ land use change, $W M C$ water management change, $T P$ combined temperature and precipitation change, TPL TP change and, in addition, land use change, TPLW TPL change and, in addition, water management change

recent past was especially distinct in the summer months (Kabas et al. 2011). These modified station data are then used as meteorological input to WaSiM, where the data are internally interpolated to grids (Schulla 2015).

Land use changes (LUCs) are implemented as variations of land use classes in WaSiM. For our LUC cases, we changed the input grid of the land use classes in two respects to create a moderate and a strong case. Because of population growth, the cities and populated areas likely become bigger, so our moderate LUC case includes the change of all partly sealed grid cells to sealed ones. With more dryness experienced over the coming decades, the vegetation will likely change into drier vegetation, challenging agricultural activities; our strong LUC case therefore includes, in addition, the change of 50\% intensive agriculture and $100 \%$ complex cultivation pattern grid cells to extensive agriculture cells, i.e., a shift to less-waterdemanding crops.

Water management changes (WMCs) are considered by introducing irrigation, which is not included in the baseline model setup. We assume irrigation with surface water and its actual use controlled by a demand-driven approach available in WaSiM. If the ratio of actual evapotranspiration to potential evapotranspiration is higher than a specific threshold, all grid cells in a specific class (land use dependent) are irrigated (Fuhrer and Jasper 2012). As limitations in water availability, the available financial resources, or other constraints are not considered, this approach potentially results in irrigation schemes that require unrealistic amounts of water. To examine the effect of different extents of irrigation, we consider two possible irrigation setups that differ in the threshold ratio of actual evapotranspiration to potential evapotranspiration. We assign all intensive agriculture and complex cultivation pattern cells for possible irrigation and use a threshold of 0.5 for the moderate WMC case and of 0.8 for the strong WMC case, respectively, like used by Fuhrer and Jasper (2012). 
Beside the individual change cases described above, also combinations are simulated to get an idea how these different human-induced environmental changes interact. In order to see the effect of total meteorological changes, temperature and precipitation are changed together (TP), with a moderate TP change of $+2 \mathrm{~K}$ temperature and $-15 \%$ precipitation and strong change of $+4 \mathrm{~K}$ temperature and $-30 \%$ precipitation (Table 1 ). As the next step, the land use changes are added (TPL) and, finally, the water management change is also included (TPLW).

\section{Sensitivity simulation results}

For instructive display and interpretation of the various environmental changes of the sensitivity study, diverse foci and formats to visualize the data are chosen (Figs. 3, 4, and 5).

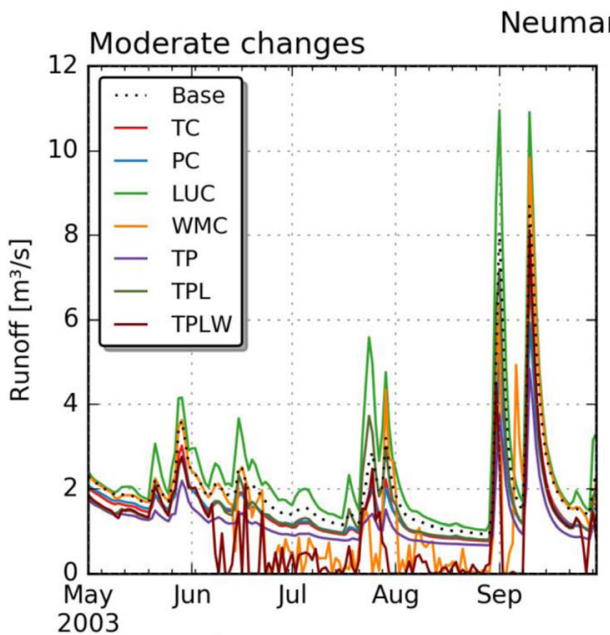

t/Raab
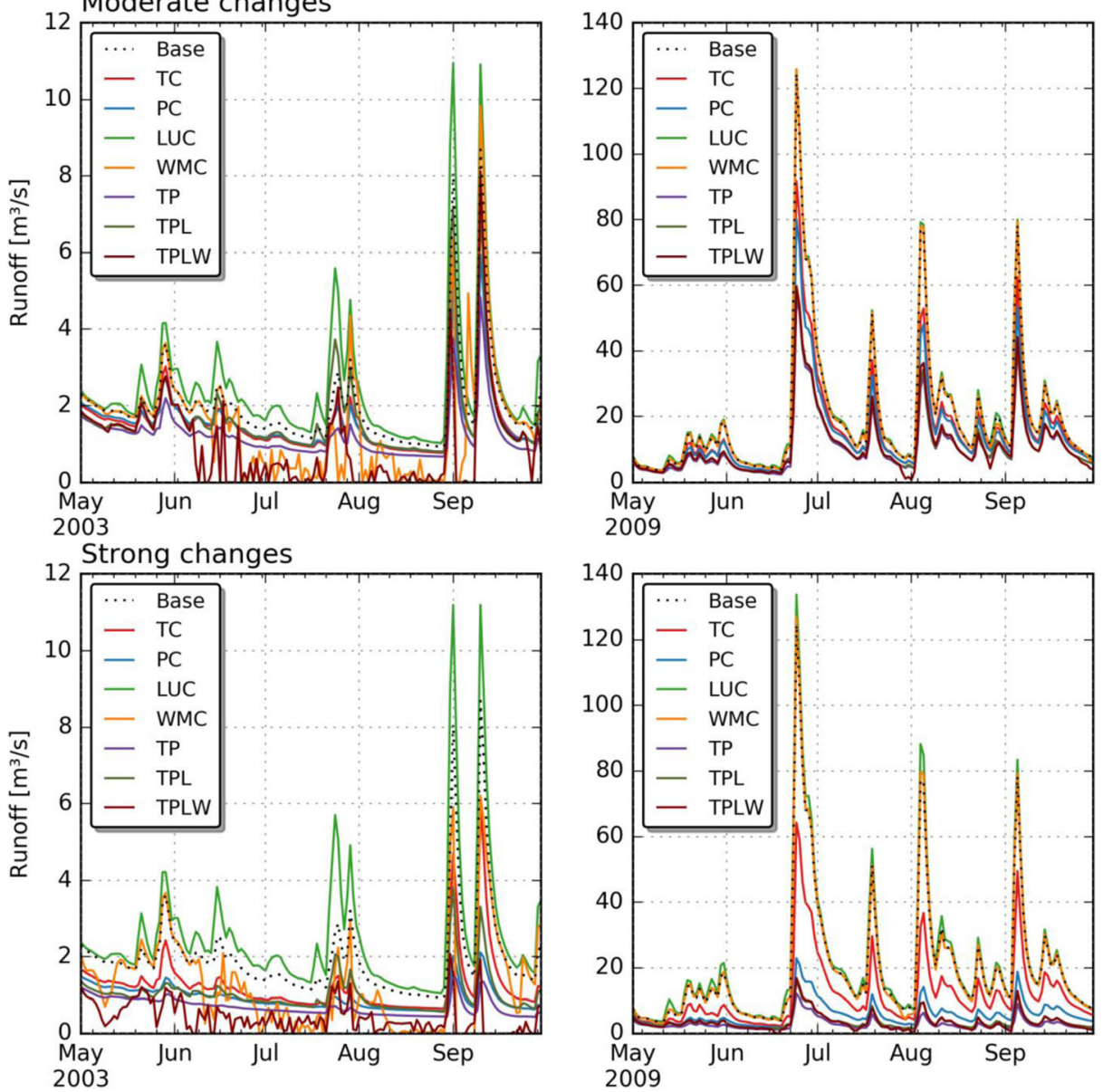

Fig. 3 Daily time series of the runoff at station Neumarkt, for the specific dry year 2003 (left) and the specific wet year 2009 (right), respectively, for both moderate (top panels) and strong (bottom panels) environmental changes 
Supplement S3 (Table S5) provides the water budget terms of the entire catchment for all considered cases.

All the environmental changes influence the daily runoff differently in various years (e.g., in specific dry/wet years such as 2003/2009) and in comparison between moderate and strong changes (Fig. 3). Especially noticeable are the WMC and TPLW cases, which clearly show the irrigation influence on the summer runoff of 2003 (Fig. 3, left panels). The moderate WMC
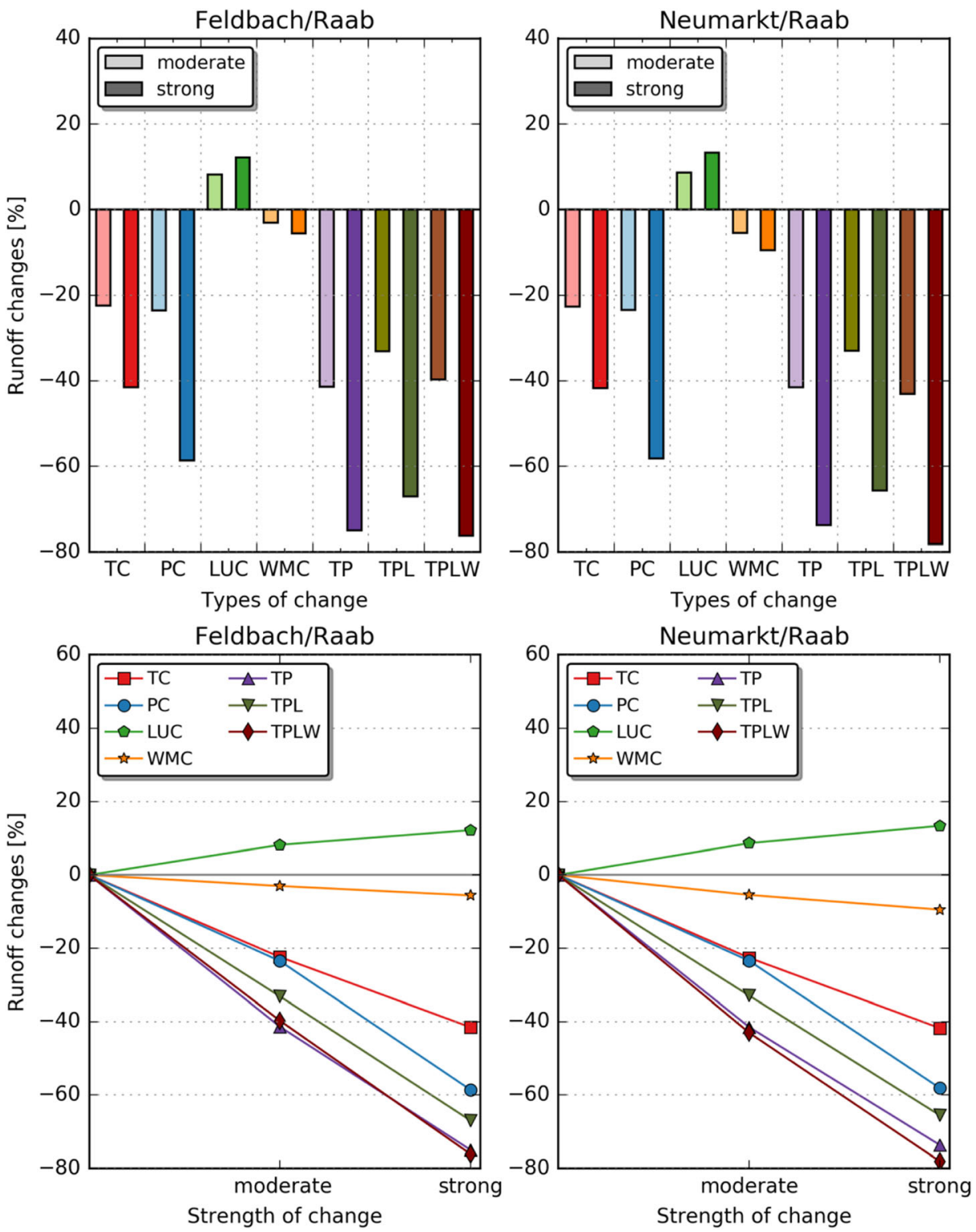

Fig. 4 Average (1982-2011) summertime (MJJAS) runoff changes for the station Feldbach (left) and Neumarkt (right), estimated for the seven sensitivity cases (types of change) for both moderate and strong changes, shown in type-based (top) and strength-based (bottom) views 


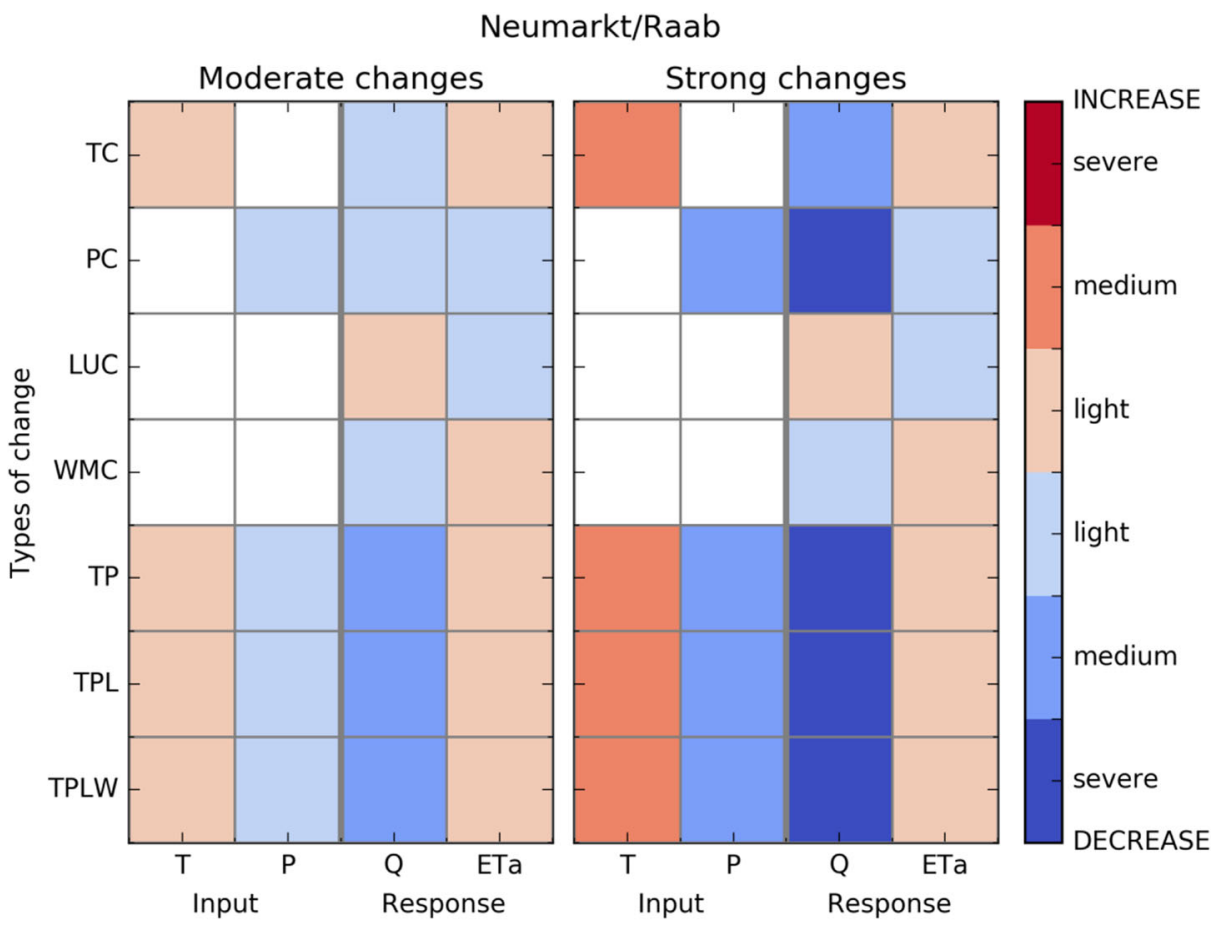

Fig. 5 Severity and direction (increase or decrease) of average (1982-2011) summertime (MJJAS) changes of the input variables temperature $(\mathrm{T})$ and precipitation $(\mathrm{P})$ as well as the response variables runoff $(\mathrm{Q})$ and actual evapotranspiration (ETa) over the whole catchment, illustrated using three severity classes (color bar at the right; light $<2.5 \mathrm{~K},<25 \%$; medium 2.5-5 K, 25-50\%; severe $>5 \mathrm{~K},>50 \%$; white = no change) for the seven sensitivity cases (types of change)

and TPLW cases are not that distinct as the strong one. For example, in May 2003, the moderate WMC does not lead to a runoff reduction as marked as the strong WMC. Between mid of August and beginning of September, the strong WMC leads to almost no water in the river for that period, under the moderate WMC only at some days. In May 2003, under moderate changes, the TP, TPL, and TPLW cases are almost the same, but by the end of May, under TPL and TPLW, more runoff is simulated. In June, the irrigation came into account and runoff in the TPLW case becomes very small.

The year 2009 is quite wet, that is why not much irrigation occurs and the discharge is mostly the same as the base run (Fig. 3, right panels). This is also the case with the effects of the LUC, which are also more distinct in the dry year 2003 compared to the wet year 2009. The meteorological changes (TC and PC) are pronounced in all years, with a much stronger runoff reduction under strong changes (Fig. 3).

The sensitivities in terms of the mean percentage runoff changes of the extended summers of the whole period of 30 years (1982-2011), for all different environmental change cases, are inspected for the lower Raab catchment stations Feldbach/Raab and Neumarkt/Raab (Fig. 4). As expected, the discharge is less sensitive to the moderate changes than to the strong changes, but the direction of the diverse environmental changes is different. The meteorological changes (TC and PC) lead to a runoff reduction, as well as the WMC, while the LUC leads to more runoff. The combined changes (TP, TPL, TPLW) always lead to negative sensitivities, towards summer dryness. The combination of all changes (TPLW) leads to the most severe runoff 
decrease (of near $80 \%$ in the strong case) in our study, directly followed by TP where only the climatic changes are acting. The runoff changes at station Feldbach/Raab (Fig. 4, left panels) compared to Neumarkt/Raab (Fig. 4, right panels) show the same general pattern, with slightly stronger runoff changes at Neumarkt/Raab.

The characteristics of model input variables temperature $(\mathrm{T})$ and precipitation $(\mathrm{P})$ as well as model response variables runoff $(\mathrm{Q})$ and actual evapotranspiration $(\mathrm{ETa})$ are finally visualized in a box diagram to better understand the input-response relationships (Fig. 5). Temperature and precipitation changes always trigger a clear reaction (TC/PC). When the changes are moderate, the combined changes (TP, TPL, TPLW) have the heaviest influence on runoff (Fig. 5, left panel). Under the strongly changing conditions, the combined changes (TP, TPL, TPLW) again influence the runoff the most, but also the strong reduction of precipitation (PC) exerts a strong negative response (Fig. 5, right panel). In total, the reaction is most visible in the runoff response, but also the actual evapotranspiration shows a light reaction up to $25 \%$. The latter exhibits a positive response to most of the changes, i.e., increased actual evapotranspiration, except for PC and LUC, which lead to decreased actual evapotranspiration.

\section{Discussion of the drought sensitivities}

The results summarized in the previous section help to analyze relative changes of runoff in response to changes of environmental conditions within the Raab catchment. Here, we provide an interpretation and discuss important implications.

Precipitation is the most important input factor in hydrological models (e.g., McCabe and Wolock 2011). In our study, the effects observed for the PC cases are also more pronounced than those for the TC cases (Fig. 4). The sensitivity study revealed a non-additive behavior of temperature and precipitation. Runoff is somewhat less reduced in the combined TP case than the additive change from the TC and the PC case (Fig. 4). This results from water availability limitations, since a higher temperature leads to more evapotranspiration only if sufficient water is available (Laaha et al. 2016). Especially for the strong changes, assuming $30 \%$ less rainfall, the water is limited on many days of the year, which leads to less actual evapotranspiration (Fig. 5).

Runoff appears less sensitive to LUC than to PC (Fig. 4) as was also found by Deshmukh and Singh (2016) who noted the land use changes as a second order control on mean annual streamflow in most of their analyzed catchments in the USA. Also, other studies show that precipitation is more important to explain changes in the runoff than land use changes (e.g., Gupta et al. 2015). In our study, the moderate LUC with more sealed areas leads to increased runoff (Fig. 4) and a reduction of actual evapotranspiration (Fig. 5). This is caused by increased surface runoff because the water has fewer areas to infiltrate into the soil and reaches the river much faster. The strong LUC, with more sealed areas plus less intensive agriculture, further strengthened the increased runoff and decreased actual evapotranspiration, because extensive agriculture needs less water than intensive one (Fig. 5).

The actual evapotranspiration is slightly increased under the WMC cases (Fig. 5), because with irrigation, more water is available for plants, especially on dry days. The water management also influences the runoff. The WMC cases use surface water for irrigation and therefore lead to decreased runoff (Figs. 3 and 4). The mean changes over the 30-year period analyzed are quite small compared to other individual changes. However, especially in dry years (such as 2003), the irrigation plays an important role since the river might fall dry if the irrigation 
water is withdrawn from the surface waters within the catchment (Fig. 3). It should thus be questioned how sustainable and realistic this irrigation scheme is.

Fuhrer and Jasper (2012) already noted that the limitation of water will be an important point in the climate change - agriculture production discussion. The irrigation demand in the future is very uncertain and region dependent (Woznicki et al. 2015). Ferguson and Maxwell (2012), for example, analyzed a semi-arid catchment in the USA under climate change versus irrigation and pumping. They conclude that climate change impacts and water management impacts on stream discharge are nearly equivalent in their study area and under their scenarios. In contrast, Tang et al. (2008) found for the Yellow River in China that human activities dominated streamflow changes only in the lower reaches of the river, whereas climate change was the dominant driver in the upper and middle reaches.

Our study additionally provides insight into the interactive effects of different human activities, namely land use change and irrigation. The TP and TPLW cases almost show the same mean runoff changes (Fig. 4). Thus, over the whole time period, the water use for irrigation compensates for the increased runoff due to the LUC, which is seen for the TPL case (Fig. 4). The evapotranspiration deficit from the LUC (Fig. 5) seems to be compensated by the irrigation water as well. Inspecting the daily runoff time series, it becomes clear, however, that TP and TPLW do not show the same behavior (Fig. 3). The example of moderate changes in 2003 at station Neumarkt/Raab (Fig. 3) shows that even with the same hydrological starting conditions for the TP, TPL, and TPLW cases at the beginning of May 2003, TPL and TPLW simulate increased runoff at the end of May, caused by the land use changes. In June, the irrigation comes into play and the runoff is hence strongly reduced under the TPLW case. Thus, within particularly dry periods, the TPLW simulates less runoff because of the water withdrawal for irrigation and, when it is wetter, the LUC dominates with more runoff.

Although these effects nearly compensate the total mean over the whole period (compare TP and TPLW in Fig. 4), the tendency to more pronounced peak flows (due to enhanced surface runoff) and reduced low flows (due to irrigation withdrawals) suggests that the runoff regime tends to more extremes (floods and droughts). Such interactive effects of land use change and irrigation thus would amplify a climate-driven increase in hydrological extremes, which may result from the expected increase in extreme precipitation (e.g., Ban et al. 2015). This might be indicated by the observed tendency towards lower minimum and higher maximum summer runoff of the river Raab (see Supplementary Fig. S2).

In order to analyze additional factors which are influenced by the environmental changes imposed, we used the actual evapotranspiration. In our model setup, the potential evapotranspiration was controlled by temperature. Also, the strong dependency, therefore, of actual evapotranspiration on the temperature is clearly visible, since changes of actual evapotranspiration are mostly combined with an alteration of temperature (Fig. 5). Our sensitivity study suggests that the enhanced evapotranspiration resulting from a warming of $2{ }^{\circ} \mathrm{C}$ causes a runoff decrease of $20 \%$.

In the Raab catchment, a temperature increase of about this size was observed within the last three decades (see Fig. 1), but the tendency towards lower runoff (Supplementary Fig. S2) appears to be weaker than suggested by the model. This might indicate that the simplified temperature-based approach causes an overestimation of evapotranspiration (Sheffield et al. 2012). Relative to the variance of the runoff time series, however, the observed tendency is not very distinct and thus highly uncertain. In addition, the Raab runoff likely is affected by direct human impacts such as river regulation, which are not explicitly considered by the model. The impacts of these simplifications on the simulated runoff thus deserve further investigation. 
Our results, nevertheless, give an initial idea how non-climatic anthropogenic changes might co-affect the runoff in our southeastern Alpine foreland catchment. We found this clearly dominated by the climatic changes that the future may hold for this region. In addition, land use changes and water use for irrigation need to be co-considered for future water resources management and its impact on runoff in the Raab catchment. The intensity of the actual runoff changes is dependent on how the forcings (environmental changes) actually unfold over time and the sensitivity of the catchment (Berghuijs et al. 2016). In this context, our sensitivity study provides valuable initial information about the potential effects of environmental changes in this and similar drought-vulnerable catchments.

\section{Conclusions}

This hydrological sensitivity study provided initial quantifications and insights to the runoff sensitivity to different environmental changes of the Raab catchment in the southeastern Alpine foreland region of Europe. We used the process-oriented Water Flow and Balance Simulation Model (WaSiM) for the analysis.

The possible future climatic changes in the region, based on trends over the recent decades and climate model projections, may include increased summer temperature and decreased precipitation, which may be accompanied by increased water use for irrigation. All these drivers lead to a runoff reduction that may be substantial in combination. Anthropogenic land use changes, including those of more sealed areas and less intensive agriculture, result in more surface runoff and less actual evapotranspiration, thus partially counteracting the runoff reduction.

More specifically, based on moderate and strong climate change cases in the catchment (temperature $+2 /+4 \mathrm{~K}$, precipitation $-15 /-30 \%$ ), optionally combined with human-induced more dry and sealed areas as well as more water use for irrigation, we found the summertime runoff response dominated by climate change. The most important single climatic driver is the precipitation change. The moderate/strong precipitation decrease was estimated to lead to more than $20 / 50 \%$ runoff decrease, together with temperature increase to more than $40 / 70 \%$ decrease (all estimates as an average decrease over a 30-year period).

The combined changes of temperature and precipitation did not lead to an exactly additive decrease of the runoff but to a somewhat less decrease, due to limited water availability. Changes in land use and irrigation were found relevant but minor contributors on average. All changes together lead to the strongest runoff decrease by nearly $80 \%$. However, analysis of the daily time series in specific dry years (such as 2003) and wet years (such as 2009) showed that the runoff evolution in individual years can be drastically different from the average estimate and that irrigation and land use change can play key roles for low flow in individual years. The expected land use changes may help reduce the overall tendency towards decreases in river runoff. However, they tend to enhance surface runoff and peak flows, thus reducing groundwater recharge and baseflow.

The actual evapotranspiration showed less distinct responses to the environmental changes than the runoff. An increase of temperature generally results in an increase of actual evapotranspiration; however, particularly in drought periods, this increase is limited by the low availability of water in the soil. In addition, irrigation leads to an increase of actual evapotranspiration, since more water is available for the vegetation in this case. 
This initial study provided clear evidence for the vulnerability of Alpine foreland catchments in this type of setting to increased summer dryness under future climate change. It furthermore showed that it is important to also include non-climatic aspects because of interactions and compensation effects of such changes. More detailed scenario-based assessments are needed as the next step to improve our understanding of how strongly the southeastern Alpine forelands are at risk of drought at the local scale of individual catchments.

Acknowledgements We thank T. Kabas (WEGC) for providing the long-term trend results, included in Fig. 1, and M. Switanek (WEGC) for the support regarding the SCE-UA algorithm used for calibration. The interdisciplinary faculty and students of the FWF-DK are thanked for the discussion and comments. The Austrian Hydrographic Service and the National Weather Service ZAMG provided the hydrometeorological station data; further auxiliary data sources (topography, land cover, soil) are summarized in Table S1. The WaSiM model was obtained via http://www.wasim.ch, and we thank J. Schulla (Zurich, CH) and W. Rieger (TU Munich, DE) for their helpful advice.

Funding information This work was funded by the FWF-DK Climate Change of the Austrian Science Fund (Doctoral Program No. W1256-G15; http://dk-climate-change.uni-graz.at) and co-funded by the University of Graz. Open access funding provided by Austrian Science Fund (FWF).

Open Access This article is distributed under the terms of the Creative Commons Attribution 4.0 International License (http://creativecommons.org/licenses/by/4.0/), which permits unrestricted use, distribution, and reproduction in any medium, provided you give appropriate credit to the original author(s) and the source, provide a link to the Creative Commons license, and indicate if changes were made.

\section{References}

Alaoui A, Willimann E, Jasper K et al (2014) Modelling the effects of land use and climate changes on hydrology in the Ursern Valley, Switzerland. Hydrol Process 28:3602-3614. https://doi.org/10.1002/hyp.9895

Auer I, Böhm R, Jurkovic A et al (2007) HISTALP — historical instrumental climatological surface time series of the Greater Alpine Region. Int J Climatol 27:17-46. https://doi.org/10.1002/joc.1377

Ban N, Schmidli J, Schär C (2015) Heavy precipitation in a changing climate: does short-term summer precipitation increase faster? Geophys Res Lett 42:1165-1172. https://doi.org/10.1002/2014GL062588

Berghuijs WR, Hartmann A, Woods RA (2016) Streamflow sensitivity to water storage changes across Europe. Geophys Res Lett 43:1980-1987. https://doi.org/10.1002/2016GL067927

Blöschl G, Montanari A (2010) Climate change impacts - throwing the dice? Hydrol Process 24:374-381. https://doi.org/10.1002/hyp

Bormann H (2011) Sensitivity analysis of 18 different potential evapotranspiration models to observed climatic change at German climate stations. Clim Chang 104:729-753. https://doi.org/10.1007/s10584-010-9869-7

Brown C, Wilby RL (2012) An alternate approach to assessing climate risks. EOS Trans Am Geophys Union 93: 401-412. https://doi.org/10.1029/2012EO410001

Bürger G, Schulla J, Werner AT (2011) Estimates of future flow, including extremes, of the Columbia River headwaters. Water Resour Res 47:1-18. https://doi.org/10.1029/2010WR009716

Carsel RF, Parrish RS (1988) Developing joint probability distributions of soil water retention characteristics. Water Resour Res 24:755-769. https://doi.org/10.1029/WR024i005p00755

Deshmukh A, Singh R (2016) Physio-climatic controls on vulnerability of watersheds to climate and land use change across the U. S. Water Resour Res 52:8775-8793. https://doi.org/10.1002/2016WR019189

Duan Q, Sorooshian S, Gupta VK (1994) Optimal use of the SCE-UA global optimization method for calibrating watershed models. J Hydrol 158:265-284. https://doi.org/10.1016/0022-1694(94)90057-4

Ferguson IM, Maxwell RM (2012) Human impacts on terrestrial hydrology: climate change versus pumping and irrigation. Environ Res Lett 7(1-8):44022. https://doi.org/10.1088/1748-9326/7/4/044022

Folini D, Wild M (2011) Aerosol emissions and dimming/brightening in Europe: sensitivity studies with ECHAM5-HAM. J Geophys Res Atmos. https://doi.org/10.1029/2011JD016227

Fuhrer J, Jasper K (2012) Demand and supply of water for agriculture: influence of topography and climate in pre-Alpine, mesoscale catchments. Nat Resour 3:145-155. https://doi.org/10.4236/nr.2012.33019 
Gädeke A, Hölzel H, Koch H et al (2014) Analysis of uncertainties in the hydrological response of a model-based climate change impact assessment in a subcatchment of the Spree River, Germany. Hydrol Process 28:39783998. https://doi.org/10.1002/hyp.9933

GISTEMP Team, 2017: GISS Surface Temperature Analysis (GISTEMP). NASA Goddard Institute for Space Studies. Dataset accessed 2017-03-10 at https://data.giss.nasa.gov/gistemp/

Gobiet A, Kotlarski S, Beniston M et al (2014) 21st century climate change in the European Alps - a review. Sci Total Environ 493:1138-1151. https://doi.org/10.1016/j.scitotenv.2013.07.050

Gupta SC, Kessler AC, Brown MK, Zvomuya F (2015) Climate and agricultural land use change impacts on streamflow in the upper Midwestern United States. Water Resour Res 51:5301-5317. https://doi.org/10.1002 /2015WR017323

Hamon WR (1960) Estimating potential evapotranspiration. Department of Civil and Sanitary Engineering, Massachusetts Institute of Technology, Cambridge

Kabas T, Foelsche U, Kirchengast G (2011) Seasonal and annual trends of temperature and precipitation within 1951/1971-2007 in south-eastern Styria, Austria. Meteorol Zeitschrift 20:277-289. https://doi.org/10.1127 /0941-2948/2011/0233

Kirchengast G, Kabas T, Leuprecht A et al (2014) WegenerNet: a pioneering high-resolution network for monitoring weather and climate. Bull Am Meteorol Soc 95:227-242. https://doi.org/10.1175/BAMS-D11-00161.1

Laaha G, Parajka J, Viglione A et al (2016) A three-pillar approach to assessing climate impacts on low flows. Hydrol Earth Syst Sci 20:3967-3985. https://doi.org/10.5194/hess-20-3967-2016

McCabe GJ, Wolock DM (2011) Independent effects of temperature and precipitation on modeled runoff in the conterminous United States. Water Resour Res 47(1-11):W11522. https://doi.org/10.1029/2011WR010630

Mishra V, Shah HL, Kumar R et al (2017) Multimodel assessment of sensitivity and uncertainty of water availability under climate change. Clim Chang 141:451-465. https://doi.org/10.1007/s10584-016-1886-8

Moriasi DN, Arnold JG, Van Liew MW et al (2007) Model evaluation guidelines for systematic quantification of accuracy in watershed simulations. Trans ASABE 50:885-900. 10.13031/2013.23153

Nabat P, Somot S, Mallet M et al (2014) Contribution of anthropogenic sulfate aerosols to the changing EuroMediterranean climate since 1980. Geophys Res Lett 41:5605-5611. https://doi.org/10.1002/2014 GL060798

Nash JE, Sutcliffe JV (1970) River flow forecasting through conceptual models. Part I-a discussion of principles. J Hydrol 10:282-290. https://doi.org/10.1016/0022-1694(70)90255-6

Oudin L, Hervieu F, Michel C et al (2005) Which potential evapotranspiration input for a lumped rainfall-runoff model? Part 2-towards a simple and efficient potential evapotranspiration model for rainfall-runoff modelling. J Hydrol 303:290-306. https://doi.org/10.1016/j.jhydrol.2004.08.026

Prudhomme C, Wilby RL, Crooks S et al (2010) Scenario-neutral approach to climate change impact studies: application to flood risk. J Hydrol 390:198-209. https://doi.org/10.1016/j.jhydrol.2010.06.043

Schulla J (1997) Hydrologische Modellierung von Flussgebieten zur Abschätzung der Folgen von Klimaänderungen. Geogr. Inst., Eidg. Tech. Hochsch., Zurich

Schulla J (2015) Model description WaSiM. Technical report, www.wasim.ch (09.03.2016)

Sheffield J, Wood EF, Roderick ML (2012) Little change in global drought over the past 60 years. Nature 491: 435-438. https://doi.org/10.1038/nature11575

Tang Q, Oki T, Kanae S et al (2008) Hydrological cycles change in the Yellow River basin during the last half of the twentieth century. J Clim 21:1790-1806. https://doi.org/10.1175/2007JCLI1854.1

Van Loon AF, Gleeson T, Clark J et al (2016) Drought in the Anthropocene. Nat Geosci 9:89-91. https://doi. org/10.1038/ngeo2646

Vano JA, Lettenmaier DP (2014) A sensitivity-based approach to evaluating future changes in Colorado River discharge. Clim Chang 122:621-634. https://oi.org/10.1007/s10584-013-1023-X

Wagner T, Themeß1 M, Schüppel A et al (2017) Impacts of climate change on stream flow and hydro power generation in the Alpine region. Environ Earth Sci 76:1-22. https:/doi.org/10.1007/s12665-016-6318-6

Wanders N, Wada Y (2015) Human and climate impacts on the 21 st century hydrological drought. J Hydrol 526 : 208-220. https://doi.org/10.1016/j.jhydrol.2014.10.047

Willett KM, Hurst DF, Dunn RJH, Dolman AJ (eds) (2016) Global climate [in "state of the climate in 2015 "]. Bull Amer Meteor Soc 97:S7-S62. https://doi.org/10.1175/2016BAMSStateoftheClimate.1

Woznicki SA, Nejadhashemi AP, Parsinejad M (2015) Climate change and irrigation demand: uncertainty and adaptation. J Hydrol Reg Stud 3:247-264. https://doi.org/10.1016/j.ejrh.2014.12.003

Yira Y, Diekkrüger B, Steup G, Bossa AY (2016) Modeling land use change impacts on water resources in a tropical West African catchment (Dano, Burkina Faso). J Hydrol 537:187-199. https://doi.org/10.1016/j. jhydrol.2016.03.052 